\title{
Retired baby boomers as operators of sustainable rural tourism: the roles and significance
}

\author{
Y. Ohe \\ Department of Agricultural Economics, Chiba University, Japan
}

\begin{abstract}
This paper examined the roles and significance of rural tourism activity undertaken by those farmers retired from non-farming jobs from a multifunctional perspective in Chiba. The results revealed that rural tourism realised efficient and sustainable resource utilisation of the farm. The main findings were: 1) the farming style of the study farm is small production of multiple products all year round, which increases opportunities for farming and farm-life experiences by local school children and urban visitors, although this type of farming was not respected from a productivity-oriented farming perspective; and 2) providing farming experience services not only makes it possible to utilise unused resources in the farmyard, but also promotes multifunctionality in terms of recreational, educational and land preservation functions. These results suggest that rural tourism will be an effective and recommended activity for those farm-oriented people retired from non-farming occupations.
\end{abstract}

Keywords: rural tourism, multifunctionality of agriculture, baby boomers, retiree farming, educational function, rural resources.

\section{Introduction}

The expected increase in the retired baby-boomer generation has been attracting growing concern in terms of its impact on society. Recently, the number of those baby boomers who have been engaged in non-farming occupations but who start or return to farming after retirement has been increasing in the recent decade in Japan. We called them "retiree newcomers" here. One reason for this increase is apparently due to the prolonged stagnant macro economy in Japan since the 
1990s, with this period having the highest jobless rate since World War II. In addition to this macro economic factor, we should consider other positive factors for farming and rural life.

A typical example of this rural orientation that contrasts with the depopulation due to movement from rural to urban areas is an increase in the number of middle-aged and retired newcomers. Some of them launch rural tourism activities. Thus it is necessary to investigate the significance of their activity for the development of rural tourism and for local rural tourism policy design in the face of the coming retirement of massive numbers of baby boomers in the near future.

Sawada [8] conducted an intensive study of newcomers into farming in Japan, and NKRI and Tabata [2005] performed a full-fledged study on retiree farmers. Bollman and Bryden [1] studied rural employment from an international perspective. To our knowledge, however, there has been no study on rural tourism conducted by retiree farmers. There are many studies on rural tourism; for instance, those by Butler et al. [2] and Hall et al. [3] and in Japan those by Ohe [6] and Nakamichi [4]. No study similar to our perspective in this report has been conducted.

To approach this aim, first this paper investigates the situation of farm resource use of retiree farmers from the viewpoint of multifunctionality of agriculture, which is recognized as a new social role of farming. Multifunctionality is associated with positive externalities that are generated along with farming activity and that exert benefits to society. Specifically, these are the sub-functions included in multifunctionality: national food security, land preservation, landscape formation, biodiversity, recreational function, succession of cultural heritage, educational function, etc. Ohe $[6,7]$ has studied the relationship between multifunctionality and farm diversification, including rural tourism, but has not yet studied issues related to retirees.

Second, this paper explores the roles and significance of retiree newcomers. Nevertheless, the number of retirees who have started rural tourism activity has hardly reached a statistically visible level at this time. Thus, the case-study method is effective here. First, we look at recent trends related to newcomers to farming in Japan and then consider features of this activity. Second, as a case study, we examine one retiree farm household, the $S$ farm in Chiba prefecture, which is conducting rural tourism activity. From this case study, we examine how this retiree farm household utilises farm resources through rural tourism activity. Specifically, we focus on the educational function of multifunctionality and clarify its features and significance.

\section{Situation of new comers into farming in Japan}

We review trends of entry of those newcomers into farming in Japan. Table 1 indicates that nearly 200,000 people newly entered into farming in 1963. Newcomers fit into two categories: those who started farming immediately after graduation of school and those who started farming by transferring from another type of work. In 1963, during the high-economic-growth period, newcomers 
were quasi-evenly divided into these two categories; those after graduation numbered about 90,000 and those by job transfer about 110,000. Subsequently, the number of newcomers dropped in both categories. In particular, the drop was sharp for graduating newcomers and continued to decrease to reach the level of less than 10,000 in the late 70 s.

Table 1: Trends of unemployment rate and numbers of newcomers to agriculture in Japan.

\begin{tabular}{|l|c|c|c|c|c|c|c|}
\hline year & $\begin{array}{c}\text { unemploy- } \\
\text { ment rate } \\
(\%)\end{array}$ & $\begin{array}{c}\text { total number } \\
\text { of } \\
\text { newcomers } \\
\text { (thousand } \\
\text { people) }\end{array}$ & $\begin{array}{c}\text { no. of } \\
\text { newcomers } \\
\text { after } \\
\text { finishing } \\
\text { school }\end{array}$ & $\begin{array}{c}\text { no. of } \\
\text { newcomers } \\
\text { through job } \\
\text { transfer }\end{array}$ & no. age $<40$ & no. age $>40$ & no. age $>60$ \\
\hline & $(1)=(2)+(3)$ & $(2)$ & $(3)=(4)+(5)$ & $(4)$ & $(5)$ & $(6)$ \\
\hline 1963 & 1.3 & 198.2 & 89.8 & 108.4 & - & - & - \\
\hline 1970 & 1.2 & 116.6 & 36.9 & 79.7 & - & - & - \\
\hline 1980 & 2 & 102.2 & 7 & 95.2 & - & - & - \\
\hline 1990 (A) & 2.1 & 15.7 & 1.8 & 13.9 & 2.5 & 11.4 & 4.8 \\
\hline 1995 & 3.2 & 48 & 1.8 & 46.2 & 5.8 & 40.4 & 24.6 \\
\hline 2000 & 4.7 & 77.1 & 2.1 & 75 & 9.5 & 65.5 & 44.8 \\
\hline 2001 & 5 & 79.5 & 2.1 & 77.4 & 9.6 & 67.8 & 43 \\
\hline 2002 & 5.4 & 79.8 & 2.2 & 77.6 & 9.7 & 68 & 42.5 \\
\hline 2003 (B) & 5.3 & 80.2 & 2.2 & 78 & 9.7 & 68.3 & 42.3 \\
\hline (B)/(A)ratio & 2.5 & 5.1 & 1.2 & 5.6 & 3.9 & 6.0 & 8.8 \\
\hline
\end{tabular}

Sources: Labour Force Survey, Statistics Bureau, Ministry of Internal Affairs and Communications, Trend of Newcomers to Agriculture, Ministry of Agriculture, Fisheries and Forestry.

Table 2: $\quad$ Results of regression analysis between number of newcomers to agriculture and unemployment rate.

\begin{tabular}{|c|c|c|c|}
\hline \multirow{2}{*}{ items } & \multicolumn{3}{|c|}{ explained variable } \\
\cline { 2 - 4 } & total no. of newcomers & $\begin{array}{c}\text { no. of newcomers after } \\
\text { finishing school }\end{array}$ & $\begin{array}{c}\text { no. of newcomers through } \\
\text { job transfer }\end{array}$ \\
\hline \multirow{2}{*}{ unemployment rate } & $18.9492^{* * *}$ & $0.1262^{* * *}$ & $18.8230^{* * *}$ \\
\cline { 2 - 4 } & $(16.24)$ & $(4.45)$ & $(16.32)$ \\
\hline \multirow{2}{*}{ constant } & $-16.9434^{* * *}$ & $1.5332^{* * *}$ & $-18.4766^{* * *}$ \\
\cline { 2 - 4 } & $(-3.80)$ & $(14.13)$ & $(-4.19)$ \\
\hline adjusted $R^{2}$ & 0.9529 & 0.5911 & 0.9533 \\
\hline Durbin-Watson ratio & 1.4199 & 1.9432 & 1.4287 \\
\hline
\end{tabular}

Source: Same as Table 1.

Notes: 1. Estimation period was 14 years from 1990 to 2003.

2. Figure in parenthes is is $t$ ratio. $* * *=1 \%$ significance.

3. No serial correlation in any result was detected by Durbin-Watson Test.

On the contrary, the number of job-transfer newcomers decreased more moderately. Still, the number sunk below the 110,000 level in the late $80 \mathrm{~s}$ and the decrease continued until the $90 \mathrm{~s}$. The number of persons in both categories 
hit bottom in the early 90s; there were 17,000 graduating newcomers in 1991 and 14,000 job-transfer newcomers in 1990. Since then, the number in either category has been increasing to reach a total of 80,000 newcomers as of in 2003. The cause of this upward trend is apparently a reflection of the climbing jobless rate mentioned earlier because the increase in newcomers has paralleled that of the unemployment rate since the $90 \mathrm{~s}$.

We confirmed this relationship statistically in Table 2. Although the regression coefficients were all positive with statistical significance $(1 \%)$, the value of the coefficient differed. The coefficient of graduating newcomers was 0.13 while that of job-change was 18.8 , indicating that a $1 \%$ increase in the jobless rate causes approximately 19,000 job-transfer newcomers. In examining Table 1, we can point out two features with regard to this large difference. The first is that the total number of newcomers increased faster than the jobless rate. Whereas the jobless rate showed a 2.5 times increase from 1990 to 2003, the number of total newcomers increased 5.1 times, which is more than double the increase in the jobless rate during the same period. When breaking down the increase by category, the increase in newcomers by job transfer reached 5.6 times while that by graduation was merely 1.2 times. In short, the recent rise in newcomers was largely due to those who had become newcomers by changing jobs. This suggests that there might be socio-economic factors other than the jobless rate affecting this reversal in trend.

To look into these factors we examined the age composition of job-transfer newcomers. Generations over 40 years old increased more rapidly than younger generations; the increase rate of job-transfer newcomers under 40 years of age is 3.9 , from around 11,000 in 1990 to around 68,000 thousands in 2003, but the rate was 6.0 times in those over 40. As a result, the portion of middle-age and senior age newcomers comprised nearly nine tenths of all trans-job newcomers. Among them the portion of those over 60 rose from three tenths in 1990 to more than half in 2003.

The reasons for this uptrend in seniors are as follows. First, those second and third sons who immigrated to urban areas during the period of high economic growth are now returning to their hometowns to take up farming after retirement. Second, those who experienced job changes under the downsizing process of the private sector chose farming for their new work and life. In any case, these reasons are influenced by socio-economic factors rather than a positive rural orientation. We cannot surely say that a real rural orientation is emerging yet.

However, at least it is safe to point out the following. The above facts suggest that support measures for newcomers in middle and senior age ought to be strengthened because traditional measures tend to be focused on younger generations. This fact also indicates that roles of middle and senior generations have been undervalued. Nevertheless, we consider that especially retirees are amply qualified for the role of a rural tourism operator as we shall see from a case study later. Therefore, in keeping these points in mind, we focus on a case study of rural tourism activity performed by a retiree couple and evaluate their performance. 


\section{Case study on rural tourism activity by retiree couple}

\subsection{Motivation for staring rural tourism}

Mr. and Mrs. $S$ run a farmhouse accommodation in $T$ town on the southern tip of Boso peninsula, Chiba. Chiba constitutes the eastern half of Tokyo Bay. This area is relatively warm even in mid winter due to a warm ocean current, and strawberry pick-your-own farming in greenhouses is conducted beginning in January. The area is traditionally famous for the Bosyu Biwa, a major variety of Biwa (loquat) fruit. However, other conditions for farming are not always favourable because of the hilly and mountainous topography, which has commonality with other rural areas in this country.

The couple had been office workers before they started the rural tourism business. The husband worked at a local bus company and the wife at a local bank. Therefore, they were type 2 part-time farmers (classification of type 2 parttime farming is indicated when household income from farming is less than offfarm income). They have 1.3 ha; 0.3 ha for rice paddy, 0.4 ha for field crops, 0.2 ha for orchard and 0.4 ha for daffodils. Daffodils are a suitable flower for parttime farmers because they need no intensive care and early shipment to the market is possible due to the warm climate.

Farming for the couple was a way of relieving stress on the weekend from their off-farm jobs. Their two sons had already become independent. In discussing their way of life after the husband's retirement, they decided to spend their life farming because they had enjoyed doing farm activities together. The wife retired together with the husband. They, however, favoured a sociable and enjoyable way of farming rather than exclusively focusing on farm production. Initially they considered a holiday rental house with small plots for vegetable production and charging 20,000 yen $(\fallingdotseq 148$ Euro as 135 yen $=1$ Euro) a week. The accommodation service law, however, does not allow tourists to cook in this type of dwelling, so they switched their plan to start an ordinary accommodation with boarding services. They have three rooms for nine people: two are western style and one Japanese style. The name of the house, " $S$ agri", came from "agriculture" and represents their affection for farm life.

They were registered as a green tourism accommodation in 1999. Green tourism is a Japanese program for promoting rural tourism that includes agriculture, forestry and fishery farms and was launched in 1995 under the administration of the MAFFJ. Registered operators are required to offer not only accommodation and board services, but also to offer visitors who request them activities unique to the countryside such as farming experience, craft making, traditional food processing, etc. The aim of this program is to provide a new income source for farmers and to give visitors a chance to relax and learn about rural life and heritage. Investment in the accommodation facility was entirely financed by their retirement allowances. The plan of the couple owning the farm was to realise sustainable farm management together with making a contribution to the local community. 
As of 2004, one difference arose that deviated from the initial plan in that the husband who had retired was requested to assume an executive post in the company where he used to work. Thus he commutes to the office on weekdays. The husband does farm work that involves machinery operation on weekends and the wife does manual farm work and accommodation-related jobs.

\subsection{Rural tourism activity}

Mr. and Mrs. $S$ accommodate about 100 visitors annually with no major fluctuations. The number of new visitors who consulted their website is greater than those of repeat visitors. Season-wise, weekend and holiday periods in May and summer are busy seasons. Visitors are mainly from the northern Chiba and Metropolitan areas of Tokyo. Although family visitors are in the majority, those who want to become retiree newcomers and male and female visitors in their 30s who are interested in agriculture and the rural environment make up more than a few of the visitors. Moreover, they annually accept about 40 elementary school children as a part of a school program in connection with their contribution to the local community.

The accommodation fee was initially 4,000 yen per night per capita with breakfast and dinner for visitors older than elementary school age. Influenced by the general deflation trend in the tourism industry due to the slow economy, they reduced the fee to 3,500 yen with only breakfast provided (3,000 yen for a child younger than elementary school age and older than the age of three). Because it is often difficult to manage to prepare dinner and conduct a farm experience program at the same time, they felt it was better to give visitors an option for eating out. Of course, meal service is offered if requested for 1,500 to 2,000 yen.

The main feature of the farm experience service is harvest experiences. A distinguishing point is that they utilise every available resource in the farmyard. In addition to multiple land use for farming, they utilise plum and biwa trees and daffodils to provide harvest experiences. Generally speaking, dairy farming can produce milk products throughout the year. For this reason, it is often said that livestock farming, including dairy farming, is more advantageous than crop farming in providing experience services in terms of seasonality constraints. Dairy faming, however, produces only milk products, which could place a constraint on diversification of the experience menu. In summary, dairy farming can provide year-round experience services with a single line of products.

In contrast, in the case of the $S$ farm, experience services involving multiple products on a year-round basis are available. We can point out the following three reasons for this: firstly, off-farm factors; secondly, on-farm factors; and, thirdly, factors related to their being retiree farmers. The first is the result of the climate in this area in that the warm winter weather enables them to conduct such a farm operation. The second is that the farm owners originally farmed part-time, growing rice and multiple field crops, which yielded only small amounts of product. All these factors contribute to enhancing efficient land utilisation for farming. In other words, this behaviour prevents abandonment of land, which often occurs due to an aging population and depopulation in rural areas. This is a land preservation function of multifunctionality. Furthermore, their small-scale 
production of multiple items enables them to widen the experience menu and to offer year-round experience services. This is an apparent advantage for conducting rural tourism although it is considered a disadvantage from a farm productivity standpoint.

Table 3: $\quad$ Farming experience menu at $S$ farm.

\begin{tabular}{|c|c|c|c|c|c|c|c|c|c|c|c|c|}
\hline crops & Jan & Feb & Mar & Apr & May & Jun & Jul & Aug & Sep & Oct & Nov & Dec \\
\hline rice & & & & & & - & - & - & 0 & & & \\
\hline radish & O & O & & & & & & & & & - & O \\
\hline cucumber & & & & - & O & O & 0 & o & & & & \\
\hline kidney bean & & & & - & o & o & o & o & & & & \\
\hline potato & & & - & - & - & O & O & & & & & \\
\hline egg plant & & & & & - & o & 0 & o & o & o & & \\
\hline gumbo & & & & & - & - & 0 & o & 0 & & & \\
\hline sweet potato & & & & & & - & - & - & o & o & o & \\
\hline sweet corn & & & & & & - & O & O & & & & \\
\hline peanut & & & & & & - & - & 0 & o & 0 & & \\
\hline aroid & O & O & & & - & - & - & - & o & 0 & O & O \\
\hline edible flower & ○ & ○ & ○ & & & & & & & & - & - \\
\hline soy bean & & & & & & & - & - & 0 & 0 & 0 & 0 \\
\hline red bean & & & & & & & & - & ○ & ○ & & \\
\hline spring citrus & & & o & O & & & & & & & & \\
\hline summer citrus & & & & ○ & ○ & ○ & & & & & & \\
\hline persimmon & & & & & & & & & & o & & \\
\hline plum & & & & & & ○ & & & & & & \\
\hline loquat & & & & & & 0 & & & & & & \\
\hline butterbur & & & & O & O & & & & & & & \\
\hline butterbur sprout & & ○ & ० & & & & & & & & & \\
\hline bamboo shot & & & & 0 & 0 & 0 & & & & & & \\
\hline mushroom & & o & o & & & & & & & & o & o \\
\hline daffodils & ○ & & & & & & & & & & ○ & ○ \\
\hline plum flower & & & 0 & & & & & & & & & \\
\hline strawberry* & 0 & 0 & 0 & 0 & 0 & & & & & & & \\
\hline flower* & $\circ$ & $\circ$ & $\circ$ & $\circ$ & $\circ$ & & & & ○ & $\circ$ & $\circ$ & 0 \\
\hline $\begin{array}{l}\text { no. of products } \\
\text { for service }\end{array}$ & 6 & 7 & 7 & 6 & 7 & 8 & 6 & 6 & 9 & 8 & 7 & 6 \\
\hline
\end{tabular}

Notes: 1. Author made based on the brochure of $S$ farm.

2. =seeding and/or planting, $\circ=$ harvesting, - =growing period

3. $*=$ contract with other farm

Table 3 shows the experience service menu of the $S$ farm in which a maximum of nine services are available in September and a minimum of four services are available even in summer and winter. On average, 6.9 services are available. Thus, the table shows that harvest experience services are available for annual field crops from early summer to winter. Additionally, harvest experience services involving fruits and daffodils can complement the seeding season of 
these field crops from spring to early summer. In short, the combination of annuals and perennials enables the farm family to offer a wide and varied menu and year-round experience services.

The third factor is that characteristics of retiree farmers who are not productivity oriented are reflected in their experience program. Specifically, the following two points should be mentioned. First, the $S$ couple takes advantage of the seasonality of each crop and realises the provision of multiple products. This is because they place emphasis upon the seasonality of agriculture and therefore do not conduct greenhouse production. Put differently, they realise a year-round operation not by extension of the production period, but by taking advantage of resource diversity that already exists in the farmyard. Second, rice harvesting is conducted not with a rice combine, but with a binder followed the natural drying of rice by hanging on rods. This is mainly because the $S$ couple originally produced rice for their own consumption. Whereas this method is rather outdated and rarely used in this era of mass production, it certainly enhances the experience program because harvesting and drying can be offered as a set of experiences in the process of the farming operation. Combine harvesting eliminates the need for manual harvesting and drying by hanging rice straw on rods because the rice combine smashes rice straw. In this mechanised production mode provision of a set of experience services from harvesting to drying is not possible. Therefore, a menu that includes extra farming experiences should be prepared. On the other hand, natural drying makes it possible to integrate harvesting, drying, and threshing into a consecutive experience program in the farm operation process. This outdoor operation, however, depends on weather conditions, so an indoor program is also prepared. For an indoor program, the experience menu varies with seasonality of materials such as making of strawberry and loquat jams and marmalade and making rice cakes using the traditional mortar and pestle. Food processing experience services are provided free of charge for overnight visitors while 1,000 yen are charged to cover the cost of materials for visitors coming only for the experience.

Furthermore, the couple sends their products by home delivery in response to orders received from visitors who have returned home. Those products include natural dried rice, handmade rice cakes, loquat, peanuts, daffodils, strawberries, etc. (Table 4). The couple buys strawberries from a relative's farm and sends rice to three consumers who purchase a 1-year contract $(3,500 \mathrm{yen} / 10 \mathrm{~kg})$. The couple has shipped daffodils to markets in Tokyo and sold them at two local farm shops. A meticulous code for size and quality is, however, required to meet standards for market shipment although prices are higher for market shipment than for direct sales at farm shops. For this reason, the couple sells belowstandard products at farm shops and by the home delivery method. As mentioned above, rural tourism activity creates demand for the direct sale of farm products in spite of the small quantity of products. These sales channels did not result in an increase in farm size, but did result in more efficient resource allocation by the direct relationship between consumers and farmers rather than only by market shipment and self-consumption of goods. 
Table 4: $\quad S$ farm's home-delivery service products.

\begin{tabular}{|l|c|c|c|l|}
\hline \multicolumn{1}{|c|}{ product } & season & unit & price & note \\
\hline sun dried rice & & $10 \mathrm{~kg}$ & 3,500 yen & \\
\hline hand made rice cake & & $2 \mathrm{~kg}$ & 1,500 yen & \\
\hline loquat & June & $3 \mathrm{~kg}$ & market value & \\
\hline raw peanut & & $2 \mathrm{~kg}$ & 1,000 yen & \\
\hline daffodils & Dec-Jan & 1 box $(100 \sim 150)$ & 3,000 yen & \\
\hline strawberry & Jan-Mar & 1 box & market value & contract with relative's farm \\
\hline
\end{tabular}

Note: Author made from the brochure and interview with Mrs $S$.

\subsection{Significance of rural tourism}

Tourism activity has the drawback of large fluctuations in operation between peak- and off-peak seasons in general. Especially in the case of rural tourism with experience services, the provision of these services is determined by the farm production cycle. In contrast, the $S$ farm can cope with seasonality through year-round provision of experience services taking advantage of the warm winter climate and small scale production of multiple items as a retiree farmer. Their behaviour eventually realises effective utilisation of unused farm resources and year-round operation of rural tourism in a sustainable manner. To summarise, production of small amounts of multiple products has been considered to be a disadvantage rather than an advantage of part-time or retiree farming from a productivity viewpoint. Rural tourism, however, creates an opportunity to bring out the potential of retiree farmers with operations having these traits. It has not been shown in the literature that this effect of rural tourism enables retired farmers to overcome what has been considered the disadvantage of being parttime and retiree farmers. Put differently, rural tourism services performed by retiree farmers shed light on the significance and advantages of farm life that have been missed even by farmers when only a normal productivity-oriented viewpoint is considered. From the multifunctionality perspective, retiree farmers with abundant knowledge of life can perform recreational and educational functions in relation to the urban consumers and local community through providing farming experience services. Additionally, it is safe to say that a yearlong farming experience program raises the land utility ratio, and from this viewpoint the land preservation function is also enhanced. In summary, it is important to recognize the significance of rural tourism activity by retiree farmers in raising multifunctionality that meets the new social demand for rurality and farming.

\section{Conclusions}

This paper investigated the significance of rural tourism activity by a case study of a retiree-farming couple in Chiba, Japan from the perspective of multifunctionality of agriculture based on taking into account the trend toward retirees becoming full-time farmers. The main conclusions are as follows. 
First, the characteristics of retiree farmers such as small production of multiple products and the preference for seasonally-based production enable these farmers to utilise farm resources effectively and enrich rural tourism in a sustainable way. This effect enhances multifunctionality of agriculture such as the land preservation function by raising the land use ratio and the educational function. What is important here is that these merits are not realised until rural tourism is launched.

Second, from a long-term standpoint, rural tourism by full-time retiree farmers would have an impact not only on local part-time farmers' attitudes on the way they manage their farms, but also on urban young and middle age generations for revaluation of the rural lifestyle.

Third, the significance of retiree farmers participating in rural tourism activities should not be underestimated. Therefore, considering the coming of the retirement of massive numbers of baby boomers, support measures for job-taking in farming should be extended to the retired and to include rural tourism because these measures have tended to be concentrated on youth.

Finally, a local tourism policy should be designed in taking into account these retiree-farmers' role in rural tourism.

\section{References}

[1] Bollman, R. D. \& Bryden, J. M., Rural Employment: An International Perspective, CAB International: Wallingford, 1997.

[2] Butler, R., Hall, C. M., \& Jenkins, J., Tourism and Recreation in Rural Areas, John Wiley \& Sons: Chichester, 1998.

[3] Hall, D., Roberts, L. \& Mitchell, M., New Directions in Rural Tourism, Ashgate: Hampshire, 2003.

[4] Nakamichi, H., Rural Tourism in Japan, Yoshizawa, S. (eds) Japanese Less Favored Areas \& Regional Revitalization, Tsukuba-Syobo: Tokyo. 139-152, 2003.

[5] NKRI (Nokyo Kyosai Research Institute) \& Tabata, T., Coming Back to Farming: Retiree Farmers and Support System (in Japanese), Association of Agriculture \& Forestry Statistics: Tokyo, 2005.

[6] Ohe, Y., Multifunctionality and Farm Diversification: A Direction for Farm Policy, Full Papers of the 80th EAAE Seminar, CD-ROM, Ghent, 2003.

[7] Ohe, Y., On the Relationship between Multifunctionality and Hamlet Activities as a Rural Institution, Japanese Journal of rural Economics, 8, pp.41-57, 2006.

[8] Sawada, M., The Diversification Mechanism of Engagement in Farming (in Japanese), Association of Agriculture \& Forestry Statistics: Tokyo, 2003.

[9] Yamazaki, M., Current Situation and Issue of Green Tourism (in Japanese), Tsukuba-Syobo: Tokyo. 2004. 